\title{
Article
}

\section{Pierre Claverie: Decolonising Mission}

\author{
Alexandru-Marius Crișan
}

check for updates

Citation: Crișan, Alexandru-Marius. 2022. Pierre Claverie: Decolonising Mission. Religions 13: 197. https:// doi.org/10.3390/rel13030197

Academic Editor: Stefan Tobler

Received: 8 January 2022

Accepted: 21 February 2022

Published: 24 February 2022

Publisher's Note: MDPI stays neutral with regard to jurisdictional claims in published maps and institutional affiliations.

Copyright: (c) 2022 by the author. Licensee MDPI, Basel, Switzerland. This article is an open access article distributed under the terms and conditions of the Creative Commons Attribution (CC BY) license (https:// creativecommons.org/licenses/by/ $4.0 /)$.
Department of History, Patrimony and Protestant Theology, "Lucian Blaga" University of Sibiu, 550024 Sibiu, Romania; alexandru13marius@gmail.com

\begin{abstract}
In the early 1980s, the Catholic Church in Algeria was experiencing upheaval, having been depopulated almost overnight when the great majority of Catholic Christians had left the country and resettled in France or elsewhere after the Algerian proclamation of independence two decades earlier. The remaining Christians were regarded not only as a reduced minority but mostly as a reminding symbol of an era of political and religious colonization. The Church in Algeria was in need of a deep reflection to find a new reason for its presence in this totally new context. A man of faith, capable of illuminating this reflection was Pierre Lucien Claverie, a Dominican friar and bishop of Oran between 1981-1996, who tried to lead the perception of the Church in Algeria from notions such as colonisation or proselytism, to notions such as otherness and plurality in an attempt to liberate the act of mission from any aggressive tendency or colonial roots. Claverie's writings show that he did not shape the concept of mission only on a theological or social level but responded to the needs of his Church through his spiritual experiences and monastic background.
\end{abstract}

Keywords: Pierre Claverie; mission; Algeria; mystical theology; interreligious dialogue; ChristianMuslim relations

\section{Introduction}

Towards the end of the 20th Century, the Church in Algeria needed an original model of mission, adapted to both the post-conciliar ecumenical and inter-religious opening, and to the new political and religious realities. Algeria was invaded in 1830 by the thenKingdom of France. The process of conquest ended in 1903 and, from that moment, Algeria's French destiny seemed a foregone conclusion. Colonisation was ended by the Algerian War of Independence (1954-1962-known also as the Algerian Revolution or the War of 1 November), and the country began a new phase with the signing of a peace agreement by France and the Front de Liberation Nationale (FLN). The decolonisation process should have been democratic, but the FLN imposed itself in a unique political party model of organisation and all the power was held by the army. Only in the late 1980s did a multi-party system emerge; in 1989 a new party appeared-the Islamist Salvation Front-and by playing on religious concerns during a period of national anxiety for the majority-Muslim population, gained significant political capital quite quickly. Faced with the possibility of a radical party winning the elections, the Algerian regime, which had been in the hands of the army since 1962, stopped the elections scheduled for 1992.

A real "chronology of dark years"1 was so inaugurated because the armed wing of the Islamist Salvation Front began a series of terrorist acts that struck at everything that represented a pluralist society, but also at symbols reminiscent of the French colonisation period: state representatives, foreigners, representatives of civil opening and religious figures. The emergence of radical Islam as a significant political force led to hundreds of thousands of victims and the departure of the majority of the remaining population of French origin in Algeria, by then only a fraction of the almost one million strong of the so-called pieds-noir ('black feet'; the colloquial term for French Algerians), who had lived in the country at the start of the $1960 \mathrm{~s}^{2}$. 
Pierre Lucien Claverie, a pied-noir himself, whose theological thinking this study aims to examine, was among the victims of the carnage created by the Islamist Salvation Front. Born in 1938 in Algiers, when Algeria was still under French rule, he was bishop of Oran from 1981 to 1996, the year of his martyric death. The religious crisis, heightened by the political conflict, forced the few remaining Christians in Algeria to reconsider the nature of their presence in a country where political Islam had already made its way into hearts and mosques. If it is not a matter of proselytism, what is the sense of Christian presence inside in a Muslim country with a renewed and strong religious and political identity? From his position as a Dominican monk, and later as bishop of Oran in Algeria-both of which conferred on him the status of missionary par excellence-Claverie embarked on a spiritual adventure that would make him reconsider the nature of the Christian mission towards Islam, in an original spiritual attempt to strip the concept of mission of its presumably colonizing character. His original views on the mission of the Church in Muslim society constitute the object of study of this present paper, necessary in a time when the reconstruction of the troubled history of many countries, such as Algeria, is still in progress. Pierre Claverie's theological thinking became more well-known in 2007, when his process of beatification started. His beatification was officially celebrated a little over a decade later, in 2018 when his martyrdom was officially recognized by Pope Francis.

To foster Claverie's theological thinking, this study intends to revisit in the first part his biography, analysing elements of his life in Algeria significant for the reconstruction of his understanding of Christian Mission. We will try to answer questions such as: was there a spiritual experience at the very base of his views on the concept of Mission? Which are the cultural and political aspects that influenced Claverie's understanding? Are there persons and encounters that shaped his understanding about Algeria and Islam? In the second chapter, we will try to extract relevant aspects from Claverie's writings through an in-depth analysis of the theological concepts that can help us in a concrete portrayal of mission in Claverie's vision.

Pierre Claverie's theological thinking is available to us thanks to the numerous articles and notes from spiritual retreats he gave during his ministry as bishop of Oran, but also because of the many studies and volumes dedicated to him. All these were published and republished in different editions, as well as in different languages. The official journal of the diocese of Oran-Le lien-was the platform used by Claverie to freely express his commentaries, analysis and views on the significative events of Algeria's political life; the commentaries also contain, as expected, non-censured condemnation messages for a politically manipulated Islam and acknowledgments of the errors of the colonial past. These letters were eventually published in a volume entitled Lettres et messages d'Algerie (Claverie 1996b). Another relevant publication is the volume Humanité plurielle (Claverie 2008a), a collection of studies belonging to Pierre Claverie on the importance of the dialogue between different identities.

Some spiritual retreats conducted by Bishop Claverie were published: Donner sa vie: six jours de retraite sur l'Eucharistie (Claverie 2003a), Petit traité de la rencontre et du dialogue (Claverie 2004), and Marie la vivante. Sept jours de retraite avec Marie (Claverie 2008b). The second one, especially, allows us to understand how important notions such as encounters, and dialogue are for Claverie's theological thinking.

After the beginning of his beatification process, several volumes or special issues were dedicated to the purpose of revisiting his theological thinking. Among these, we first mention his main biography: Pierre Claverie: Un Algérien par alliance (Pérennès 2000); translated into English (Pérennès 2007a) and Italian (Pérennès 2004), written by who we consider to be Claverie's main biographer, Jean-Jacques Pérennès. He has also published studies (Pérennès 2007b) or edited volumes. A good example in this sense is the volume Pierre Claverie, la fécondité d'une vie donnée (Pérennès 2018b), prefaced by the late Cardinal Jean-Louis Tauran and already translated in Italian (Festa 2019a, 2019b). In 1997, the review La vie Spirituelle dedicated a special issue to the figure of Pierre Claverie. 
Pérennès confirms our intention of presenting Claverie as a mystic, linking him to Christian de Chergé, another well-known spiritual figure of Algeria, in one of his papers, even if de Chergé is a more evident mystic, since he had a contemplative life as the prior of the monastery of Tibhirine (Pérennès 2018a). The link between the two mystics is explored also by Claudio Monge and Gilles Routhier in a volume published in French: Osez l'hospitalité-l'hospitalité à l'école de Pierre Claverie et Christian de Chergé (Monge and Routhier 2019) and translated in Italian (Monge and Routhier 2020).

Other information about Claverie's ministry and other representative figures of the Church of Algeria, official messages from the part of the Holy See regarding the bishop of Oran can be found in the review Islamochristiana, edited by the Pontifical Institute for Arabic and Islamic Studies; for example: "In Memoriam. Léon-Etienne Duval, Pierre Claverie et Christian de Chergé" (Borrmans 1996).

One must not forget the correspondence of the Claverie family. Most of the letters written by Pierre Claverie to members of his family were published in three volumes: $I l$ est tout de même permis d'être heureux-Lettres familiales 1967-1969 (Claverie 2003b); Cette contradiction continuellement vécue. Lettres familiales 1969-1975 (Claverie 2007); Là où se posent les vraies questions. Lettres familiales 1975-1981 (Claverie 2012).

\section{Un Algérien par alliance. A Biography Read in the Light of the Mission}

The following is not supposed to be a simple revisit of Claverie's already-known biography but mostly a rereading of it, with an emphasis on what is truly relevant for the construction of the concept of Mission according to his theological thinking.

Who was this atypical figure of the Catholic Church in Algeria and where does his originality lie? In an interview he gave for the Journal L'Actualité religieuse in 1995, Claverie described himself as "Cheick" chrétien, bishop of a huge diocese as territorial expansion but tiny as number of souls" (Claverie 1995b). There are more than just words to this description. Claverie tried to understand himself through somebody's else identity and through his experience of the Algerian world. He was always in search of authentic encounters, despite the complicated political and historical context of the last decades of the twentieth century in Algeria.

\subsection{Pierre Claverie of Algeria. Le Pris de Conscience-A Call for Other Kind of Mission}

Pierre Claverie was not a migrant, nor a refugee, but a member of a pied-noir family living in Algeria for four generations and residing in the main European quarter of Algiers. He was born on 8 May 1938 in Algeria and grew up in a very pious, educational environment. Pérennès observes the dominant characteristics of Pierre Claverie's childhood: the extraordinary unity of his family (Pérennès 2019, p. 38); parents who loved each other, and good communication between generations, as rare a quality back then as it is today. Pierre and his sister, Anne-Marie Gustavson-Claverie, after leaving the family nest, maintained correspondence with their parents until they died ${ }^{4}$. The family's unity must have been the foundation for Claverie's extraordinary capacity of communicating with other cultures and identities, maintaining for all his life an inner balance and solidity.

The question of the other identities and cultures came to young Pierre's attention during his university studies in Grenoble, in France, beginning with 1957. Due to the many discussions and the agitation created in the French universities regarding the Algerian quest for independence, he was briefly tempted to join some extreme-right movements, but he would abruptly abandon the idea at the recommendation of his father (Pérennès 2019, p. 38). He soon discovered another facet of Algerian culture that marked and enriched his existence.

It was during his years of university studies spent in France that Claverie understood that his entire childhood and adolescence had been lived in a colonial bubble, not having had a real coexistence with the Arabs. Claverie writes that despite the many homilies he heard about the neighbour, he never realized that the neighbour was also or especially the Arab. He thus recalls: 
I lived my childhood in Algiers in a working-class neighbourhood of that cosmopolitan Mediterranean city. In contrast to other Europeans born in the countryside or in small towns, I never had Arabic friends—not at the local elementary school, where there were no Arabs, nor at my high school, where they were only a few and where the Algerian war was beginning to create an explosive environment. We were not racist, merely indifferent, ignoring the majority of the people in this country. They were part of the landscape of our outings, the background of our meetings and of our lives. They were never equal partners. (Claverie 1997b, pp. 723-24)

The new spiritual landscape that appeared moved Claverie's attention towards what he calls the other. Claverie wrote in an autobiographical essay ${ }^{6}$ : "because I ignored the other or because I denied his existence, one day he suddenly leapt right in front of me. He burst open my sheltered universe ( . . . ) and asserted his existence" (Claverie 1996a, p. 114). The discovery of the other-existent outside his bubble - was the real seed of his vocation for a mission of dialogue, being the very beginning of a journey and of a path that began in the colonial bubble and ended in the heart of the other. The notion of bubble became quite central in Claverie's reflections; he would develop the concept of colonial bubble to Catholic bubble, Christian bubble and even Western bubble (Monge and Routhier 2020, p. 53). Being a prisoner of the bubble was a serious and tragic characteristic of Claverie's childhood; he wrote in this sense that "it was necessary a war to free myself from the bubble" (Claverie 1991, p. 15). This powerful spiritual experience would mark forever his image about concepts such as otherness, preaching, encounter and conversion; this pris de conscience was his prerequisite for developing an original concept of mission and Christian presence in the "lands of Islam".

The serenity used by Pierre Claverie to present this aspect of his youth indicates that somehow it was not or not only out of nostalgia that he surpassed the limits of his colonial bubble, but the real reason lies in a deeper experience that drove him towards religious maturity, predisposing him to a profound understanding of the cultural identity of Algerian society. Claverie would work all his life to make up for the missed encounter from the time of his childhood. He would do everything possible to fully enculturate himself in the Algerian society by learning Arabic and by trying to "spiritually" encounter Islam, despite remaining a profound and devout Christian in his identity. This was one of the rare cases in which a country was, at the same time, the country of one's birth and the country of one's adoption. He managed in this way to give a spiritual sense to his French roots and free himself from an ethnofiletistic ideology.

Claverie's ecclesiastical path, similar to many other life choices and aspects of his life, was very much influenced by Cardinal Léon-Étienne Duval, Primate of the Catholic Church of Algeria, who would ordain Claverie as bishop of Oran many years later. Many aspects of Pierre Claverie's understanding of Church-Algeria relations can be explained by looking at some choices made by Cardinal Duval himself, such as championing for an independent Algeria, protesting in early 1962 against European military interventions, to the anger of the pieds-noirs, who called him "Mohammed Duval", opposed the Action Française, a movement, supporting a Catholic established state-religion, sustained anti-imperialist ideas and encouraged peace between religions ${ }^{7}$. Under his guidance, Claverie started his journey towards developing Algerian routes. He started by studying the Arabic language immediately after his return to Algeria in 1967 with the community of the Lebanese nuns of Algeria, where he celebrated Mass every evening. This community was frequented by many Algerian students, mostly Muslims. Entering in this large group of friends, Claverie felt he was meeting all the friends he could not have during his "colonial education" (Pérennès 2004, p. 107). The prior of this community, Sister Atina Fadil, "adopted" 8 him and guided him in the process of coming closer to indigenous Algerian culture, which, at that time, was experiencing a popular movement to rediscover its Arabic background. Returning to the Arab origins was an important element of the reconsolidation of an independent Algerian culture, which is why the young Pierre Claverie worked intensively for almost a 
decade to acquire a good level of understanding of Arabic. For Claverie, learning Arabic was an absolutely necessary step to make towards "the overcoming of the abyss that separates us" ${ }^{\prime \prime}$.

Another important fact that shaped his enculturation was discovering Islam. During his years of studying Arabic, he formed a close friendship with Mohammed El Badry, an Egyptian author of books on Sufism, with whom he had many discussions. The fact that Claverie's first intellectual contact with Islam was through Sufi thought is an important point to note when it comes to his perception of Islam. Many other remarkable friends introduced him to daily Algerian life; Pérennès summarises this aspect very well by writing that "a precious network of friends taught him the rest, those things that are beyond words and that are learnt only by sharing with other's one life, with its joys, its struggles, and its pain" (Pérennès 2007b, p. 138).

On 25 May 1981, he was appointed bishop of Oran ${ }^{10}$, being consecrated bishop by Cardinal Léon-Étien Duval, who led the Church of Algeria in those dark times. During his speech on the occasion of his consecration in Algiers, the new Bishop Pierre Claverie paid a vibrant homage to his Algerian friends, being able to give a spiritual dimension to their encounters, lived as a deep friendship:

My Algerian brothers and friends, ( . . ) to you I owe the fact that I discovered Algeria, which was still my country, even though I lived there as a foreigner all my youth. With you I learned the Arabic language, and, above all, I learned to understand and speak the language of the heart, the language of brotherly friendship in which all races and religions communicate. (Claverie 1997c, pp. 701-2)

Later, as bishop of Oran, Pierre Claverie had an even more diverse group of friends. Some notable figures with whom Pierre Claverie became acquainted with were Sheik Mehdi Bouabdelli, a history scholar and member of the Algerian Islamic Superior Council, and Sheik Abbas Bencheick El Hocine, dean of the Grand Mosque of Paris, who even invited Claverie to deliver a speech there in 1988.

\subsection{The Algeria of Pierre Claverie. A Mission Developed in Times of Political Decolonisation}

The life and the testimony of Pierre Claverie cannot be completely dissociated from the tragic events that marked Algeria during "the black decade" — the 1990s—which led to almost 200,000 deaths, most of them Muslims.

The rise of radical Islam in Algeria took place in several stages. The manner in which it was introduced to the country and its people led to a spiral of violence, sometimes resulting in massacres such as the one in Benthala on the night of 22-23 September 1997, when five hundred people lost their lives. The year of 1997 was the bloodiest, with several thousand people losing their lives. Faced with the inability to stop these massacres, the government of Algiers tried to negotiate with the Islamist Salvation Front on several occasions. The negotiations ended in 2005 with the publication of a Charter for Peace and National Reconciliation, at the cost of having some of the perpetrators given amnesty and a sense that the process of justice was incomplete.

The assassination of Christian clerics in Algeria began on 8 May 1994, when Sister Paul Hélène Saint-Raymond and Friar Henri Vergès were attacked. The so-called Armed Islamic Group claimed responsibility for the assassination without hesitation, mentioning in the communique that they wanted to eliminate "two crusaders who have long spread their ideas in Algeria" (Festa 2019a, p. 12). The long presence and activity of these missionaries seem to have been perceived as an attempt to evangelize and spread Christian ideas. While the crimes against Christians in Algeria must be considered in the context of political unrest on one hand, one should not ignore that the collective perception of the Christian mission in Algeria was still one of political colonisation. Faced with such events, Pierre Claverie mentioned, back then, in a message, the charged history that each of these communities has, writing: 
... we have both inherited an image of the other that is superimposed on reality. At every moment and, especially in times of crisis, terms such as the warriors of Allah, the Turkish or Moors invading Europe emerge in the Western imaginary and discourses while the Muslims always remember the Crusades and the period of colonialism. (Claverie 1997d, pp. 705-6)

The fact that almost a hundred imams were also killed in this period confirms that it was more than the views on the mission that was the real problem behind the murders perpetrated against clergy, even if the mentioned stereotypes about the mission played a significant role that was easily leveraged for those wanting to manipulate the society towards religious violence. During spiritual retreats, Pierre Claverie criticised an image of the Christian mission that was very persistent in the Algerian and French mentality at that time. It refers to a relevant cover-image of a book about the first years of the "French" Algeria, written by a military chaplain, Abbot E. Munoz, entitled Sur les pas du drapeau ${ }^{11}$. The image speaks for itself ${ }^{12}$, and the explanation of the bishop of Oran is more than clear:

On the gravel on the seashore there were French officers dressed ( . . ) in uniforms and there was also a majestic ship that reached the shore (...). A bishop in liturgical vestments was descending and the officer with the rifle in one hand extended the other hand to allow the bishop to reach the African shores. On the day when a bishop set foot in this way in Algeria, the seeds of the War of Independence and of the rejection of Christianity had already been sown. (Claverie 2015, p. 40)

This kind of approach sends a clear message: the mission is protected or facilitated by the military force and the Church "steps" behind the army, "sur les pas du drapeau". From this point of view, the Christian mission in Algeria was nothing more than a consequence of the military conquest of these lands. Unfortunately, these stereotypes, still present in the Algerian mentality, came from a sad but real history that was fully exploited later on in the context of a nationalist awaking. The Christianisation of Algeria and its political colonization went hand in hand and many clerics believed that France had a providential mission to convert and civilise Africa. Relevant in this sense is the case of Archbishop Charles Martial Allemand-Lavigerie of Algiers (1825-1892), who considered the French invasion as being a providential event ${ }^{13}$ that needed to be religiously exploited. Lavigerie, the first archbishop of Algiers, campaigned for the religious conversion of Muslims and made several steps towards this goal. For example, he organised orphanages for the many Algerian children orphaned by famines and epidemics of that period. As expected, most of those children converted to Catholicism. ${ }^{14}$ Another important step was the foundation of the Society of Missionaries of Africa, known as White Fathers (in 1868), and of the Missionary Sisters of Our Lady of Africa, known as White Sisters (in 1869), having the mission to "convert the Berbers" (Naylor 2010, p. 725).

This was the complicated reality inherited by Pierre Claverie as an Algerian bishop, and he was entirely aware of it (Claverie 1996b, p. 146); it was to this mentality that he needed to react when the terrorist attacks happened. Claverie was not silent about the mistakes of the Church throughout history, but he was also not silent about condemning terrorist attacks or instances of manipulating religious ideas used to serve political agendas. Of course, the risk of such condemnations was enormous. His messages were published at that time in the official journal of the diocese of Oran-Le lien. Among these interventions condemning terrorist attacks, one published on the occasion of the murder of a nun named Odette Prévost (17 July 1932-10 November 1995) stands out. It is entitled Bravo! This editorial is considered by Gianni Festa, one of Claverie's biographers in Italian, to be one of his clearest and most lucid texts (Festa 2019b, p. 31). The irony used by Clave-rie shows his great pain for the events and presents a strong warning signal of the damage produced by continuing to mix religion with political agendas:

Bravo! Well done to you, the heroes of justice who have struck again, have long analysed the political situation in the country, developed a strategy, chosen the 
most significant victims, tried to influence public opinion and change the balance of power throughout history. ( . . ) Well done to you who have chosen this kind of war that you call jihad, a holy war against the enemies of God, of tyrants and exploiters, corrupt and hypocrites, infidels-Jews or Christians. (Claverie 1996b, pp. 177-78)

The messages given by the bishop of Oran of that period suggest a courageous man trying to "exorcise" the political reality of his times by "missionaries" who thought they exclusively possessed God and the whole religious truth, being allowed to act in the name of God. The words from the same message are eloquent in this sense, both for Christians and Muslims: "Years later-or betters said centuries later-(...) you have studied the Holy Writings, deepened the divine intentions, discovered the will of God ( . . ) and decided to purify the world ( . . . )" (Claverie 1996b, p. 177-78). Claverie is convinced that "no ideology, no political project could justify the many crimes every day" (Festa 2019b, p. 31) and reacted by trying to justify the Christian presence through a reconsidered insight to the mission.

\section{A Genuine Christian Mission According to Pierre Claverie}

A closer look at the different concepts Pierre Claverie addressed during his ministry allows us to reconstruct a clear image of what he intended the mission to look like. The unifying key of reading all the concepts analysed below is Claverie's original understanding of plurality.

\subsection{Encountering the Other in Truth and Truths}

Pierre Claverie was neither a nostalgic nor idealist, but rather a very rational spirit. In fact, unlike other young priests of the post-conciliar era, he was not inclined towards revolutionary movements. Claverie's reflection was made in the light of the Second Vatican Council which was taking place during in those years. Pierre Claverie had a definite spirit of openness and encounter, but when addressing the matter of inter-religious dialogue, was not thrilled with themes such as those present in the second, third and fourth chapters of Nostra Aetate. Claverie constantly rejected the emphasis placed on ideas such as a unique God, brothers in Abrahamic faiths, religions of the book, etc.-all of these being an exaggerated quest of underlining what is common for Jews, Christians and Muslims. ${ }^{15}$ Indeed, many argue today that time and experience have shown that ignoring what truly divides monotheistic religions leads to an even greater alienation between them, leading to today's worrying situation when religions look at each other with fear and distrust.

The Secretariat for Non-Christians (later known as Pontifical Council for Interreligious Dialogue), inaugurated in 1964, organised many interesting Islamic-Christian conferences, but Claverie never attended these large gatherings. In 1987, he was appointed part of the Pontifical Council for Interreligious Dialogue. This position "gave him the chance to temper the enthusiasm of many of those specializing in dialogue" (Pérennès 2007b, p. 138). Claverie called these great inter-religious events where long and internally ineffable speeches were delivered "a dialogue of the deaf, a continuous imposing of one's own monologue, a sharing of affirmations without real questions" (Claverie 1986, p. 7) and without a real inner questioning. Henri Tessier observes that Claverie preferred the expression "dialogue of religious experience" (Tessier 2019, p. 78). Rejecting the way of the official dialogue, where few experts decide what unites Christian and Islamic doctrines by putting aside the differences, Pierre Claverie preferred the way of plurality by entirely confessing each identity in an attempt to fully enter the truth of the other, not for a simple informational activity, but to make our religious truths useful for the world and society. He thus wrote: "if we only have affirmation to share, then we can only move beyond an exchange of information to enter into an argument (...) Rather than ramming our truths down each other's throats, is not it better to listen to each other and listen together to the questions raised by the developments of our world?" (Claverie 1986, p. 7). 
When approaching this issue, Claverie does not in any way minimalize the Christian truth but rather takes into serious consideration the difference of the other and this, according to Pérennès, "is one of his original contributions in this field" (Pérennès 2007b, p. 139). Of course, he follows the already traced line of Gaudium et spes or Dignitatis Humanae but manages to go further, because Claverie not only wants a face-to-face meeting or an inter-religious collaboration for peace in the world, but he has the inner spiritual courage to put himself in a delicate position by making his own relationship with God dependent on the relationship with the other, keeping, entirely, the truth and the identity of whatever otherness means. He thus prefers a relationship with the other entirely. In 1994, the bishop of Oran wrote:

At this moment, the key word of my faith is dialogue, not because this is a strategic choice ( . . . ) but because I feel that dialogues constitutes the relation of God with people and of people with each other. ( . . ) May the other, may all others, be the passion and the wound through which God will be able to break into our fortress of self-satisfactory. (Claverie 1995a, p. 36)

This attitude towards the concepts of otherness, truth and identity is extremely relevant for the significance of the mission, because, in Claverie's theological thinking, the direction of the mission is, in fact, reversed. The object of the mission thus becomes, not the other, but the very self; one does not embark on a mission to convert the other but to meet the other in his own truth and identity, without denying their own religious identity. There is actually no need to impose a certain truth because, according to Claverie, "no single person possesses the truth. Everyone is looking for it" (Claverie 2008a, p. 330). He even speaks about the "truth of the others"16.Claverie adopted for his theology a specific image of God-the One who is beyond human truths and impossible to be contained by them. The more he roots himself in this apophatic image of God, the more he manages to free himself from an idolatrous attitude towards the truth ${ }^{17}$, opening himself with courage to the real other; listening to and being with the other is a must for his spiritual life.

As soon as we claim-and in the Catholic Church we have had this sad experience during our history-to possess the truth or to speak in the name of humanity, we fall into totalitarianism and exclusion. (...) There are certainly objective truths, but they are beyond all of us, and one can reach them only through a long journey and by slowly recomposing that truth by collecting from other cultures, from other types of humanity, what others have also gained, have searched for in their own journey toward truth. I am a believer. I believe in one God, but I do not claim to possess that God, either through Jesus who reveals him to me, or through the tenets of my faith. One does not possess God. One does not possess the truth, and I need the truth of others. This is the experience that I am having now with thousands of Algerians in the sharing of an existence and the questions that we all ask ourselves. (Claverie 2008a, p. 330)

At a first glance, one might say Claverie was a complete pluralist who did not think any single religion (including his own one) has greater truth or is more effective in apprehending the divine. Christian Salenson notes that Claverie's vision of truth and truths goes beyond a mere acceptance of religious plurality in a social sense (Salenson 2020, p. 36). Claverie understands plurality in a spiritual sense as the existence of different paths leading to God, paths that need to be contemplated. This aspect was also addressed by Claudio Monge and Gilles Routhier, who wrote that for Claverie, what was "important was not to bring the other to one's own truth by taking him hostage under the tent of the own religious certainty, but to try to understand which is the meaning in the economy of salvation of these other ways towards God" (Monge and Routhier 2020, p. 72). From this point of view Claverie seems to have been attracted to the idea of differentiated revelation (Monge and Routhier 2020, p. 72), a concept that might have been inspired to him by the Dominican fellow Claude Geffré; our author even quotes one of Geffrés papers on this topic (see: Geffré 1985). Instead, the author believes that this is just half of the truth. It is not enough 
to say that Claverie really believed in plurality as a way of encountering God, as one must add that this conviction had, for Claverie, a Christian Christological base. Relevant proof, in this sense, is Claverie's original understanding of the Cross, which will be focused on in a further subchapter. In the words of Claverie himself, it is through "the Crucified Messiah" (Claverie 1997a, p. 834) that he understands the need to be and to maintain a humble dialogue. His Christian identity and his views on religious plurality was harmonised in him by the image he had of Christ. Claverie writes that the birth and death of Christ is proof that "God is beyond any human representation including the Christian one" (Claverie 2004, p. 81) and thus "God is transcendent" (Claverie 2004, p. 81). The author would suggest that reflection on the transcendence of God, inspired by the kenotic image of the birth and death of Jesus Christ, allowed Claverie to take a certain prospective distance and to find himself fine with the differentiated revelation. Without this understanding of the spiritual plurality of salvation, the Christian mission, according to Claverie (1997d, p. 712), will always be marked by proselytism and aggression. Certainly, this vision is also conditioned by the idea of the sacredness of human otherness, having the same Christological base.

Pierre Claverie is definitely not "typical of those that contributed to the religious change in attitude towards Muslims that found its most profound expression in the documents of Vatican $\mathrm{II}^{\prime \prime 18}$, but we can still assume that although bringing surprising readings that put him at odds with his own tradition, he remains acceptable to his ecclesial RomanCatholic teaching. When he speaks about the "truth of the others", Claverie comes closer to Nostra Aetate, even if with a slightly different perception ${ }^{19}$. An Abrahamic ecumene, considered as being something artificial by Claverie, is not fully accepted, not even by Nostra Aetate (Sudworth 2014, p. 469).

\subsection{Freeing the Mission from Aggression}

As has been already mentioned, when Pierre Claverie assumed the office of bishop of Oran in 1981, the Church in Algeria had already begun confronting certain stereotypes, many of which referred to the notion of mission. The new bishop completely assumed this situation and had not avoided mentioning this charged history from his very first sermon. Claverie was faced with an inherited mentality, where notions such as Christians, Missionaries, Aggressors, Crusaders, and Neo-colonialists were all synonyms united by a stereotypical link. To break this link, Claverie achieved "a renewed look at the mission" (Pérennès 2007b, p. 140). Thus, in his first sermon, Claverie said:

Yes, our Church is sent on a mission. I am not afraid of saying it ( . . ). Many misunderstandings inherited hang over the mission and missionaries. Let us say clearly today: we are not and we do not want to be aggressors. ( ... ). We are not and we do not want to be the soldiers of a new crusade against Islam, against the absence of faith, or against anyone. We do not want to be agents of an economic or cultural neo-colonialism that divides the Algerian people to better control them. ${ }^{20}$

Claverie understood that the Algerian situation was a debacle in a period when the very right of a diverse existence, the right of otherness, was an object of negotiation. A certain religious view, by bringing in the feeling of possessing God and His absolute truth, seemed to enforce the need to exclude the other (Monge and Routhier 2020, p. 58). Pierre Claverie was always aware of the "emergency" of the colonial perception of Christian presence in the Algerian society, mentioning it in different writings. Claudio Monge and Gilles Routhier agree that the objective of Claverie's mission in Algeria was to overcome this perception by "learning to live together" (Monge and Routhier 2020, p. 58); this was an absolute need in the Algeria of those times, as it still is now in so many parts of the world. The bishop of Oran chose concepts such as love, friendship, companionship, acceptance, coexistence, listening, respect and distance to obtain this goal. This is what mission represented to him: 
We are not and we do not want to be evangelical proselyters who think they honour God's love by a tactless zeal and a total lack of respect for the other, for his culture, for his faith. However, we are and we want to be missionaries of the love of God, as we have discovered it in Jesus Christ. This love, infinitely respectful of humans, does not impose anything, does not coerce coincidences and hearts. (Pérennès 2007b, p. 140)

The mention of Jesus Christ shows clearly, once again, that for our author, all the qualities that define mission, as well as openness to other identities, are framed in Christ. However, the binomial proposed by Claverie is not easily accessible for a superficial understanding of religion. How can we truly encounter Islam in all its difference, without relativizing, at the same time, the salvation and the revelation obtained in Jesus Christ? The Bishop of Oran proposes a seemingly simple declension of the Christian's mission in the lands of Islam, namely the almost banal daily coexistence in the spirit of respect and hospitality but animated by love. It is because of a profound love discovered and rooted in Jesus, so in his own spiritual identity, that Claverie wants to enable all to gain a peaceful co-existence marked by plurality. This is the spirit that drove him to a deep understanding of the encounter. Out of respect for the encounter with the other, Claverie sustained the need for reshaping our interior spiritual geography to favour a natural encounter and not an artificial one.

In a quest to symbolically express these aspects, Pierre Claverie writes that the organization of human space is a consequence of inner geography. From this point of view we can take into consideration the ancient cities built around mosques or churches, those radio-concentric cities with short and narrow streets presented in contrast to the usual modern cities in the shape of a chessboard, with long wide streets where encounters happen. The discourse on the geography of inner and outer spaces led Claverie to speak practically of a strategy of encounter. For the oriental world that inspired our author so much, in the middle of such a strategy lies not so much effort or strain, but simply the threshold of the door (Claverie 2004, p. 32). The casual but authentic and natural discussion in the doorway is, according to Claverie, a true constructive mission based on everyday life and not on formal planned meetings (Claverie 2004, pp. 27-32).

Another obvious aspect that the bishop finds necessary in the process of healing the mission from the tendency to aggression is respect for distance. The already-mentioned threshold of the door is a limit in a spatial plan, but we can move the speech toward an identarian plan or religious plan. We would normally point toward a lifting of masks, in a needy desire to sanction falsity. However, not Claverie, he, on the other hand, recommends not tearing off the masks, not forcing the interiority of the other to open up before being a truly free act, free of any artificial effort. This fact has nothing to do with a false identity, but with stripping the desire of encounters and of any kind of aggression that could crush a fragile person. He wrote: "Do you know what's behind the masks? Have you ever thought that maybe some people have built an entire identity based on a mask in order to survive?" (Claverie 2004, pp. 46-47) Despite being inspired by the reality of the Islamic world, Claverie's original approach to masks and distance could be also interpreted from a mystical perspective; the mask represents the presence of the divine, as it was in the Old Testament. Even, or mostly when masked, the other becomes a means of contemplating the divine mystery. This contemplative state comes as strong opposition to a proselytist and aggressive attitude toward the other. Again, the object of the mission is reversed, and the missionary is actually searching for his own conversion to a deeper contemplation of God's mystery through an authentic encounter with the other.

\subsection{A Renewed Sense for the Notion of Crusade. The Cross-The Supreme Gain of the Mission}

However, in the theological process of disarming the concept of mission, the supreme gain is a renewed understanding of the suffering inspired by the Cross. Not only are the colonial past and aggressions put aside through a contemplative attitude, but one needs "to be able to meet death with no other baggage than a disarmed and disarming love that 
dies forgivingly" (Claverie 1996b, p. 151). Accepting suffering must be rooted in the love of Christ, otherwise, according to Claverie, it risks being driven by masochistic tendencies that have nothing to do with the Christian mission. When the attacks on Christians in Algeria increased, Pierre Claverie and others like him had to choose whether or not to stay. Claverie confesses that the decision to fulfil the mission must be taken in the light of the cross:

We are in Algeria because of this crucified Messiah. We are not driven by who knows what masochistic or suicidal perversion. Because of Jesus because he is the one who suffers here in this violence that forgives no one and in which he is crucified again in the flesh of thousands and thousands of innocents. (Claverie 1997a, p. 834)

Claverie understood the suffering through his own spiritual identity, in the footsteps of "his" Messiah. According to the words and life of Pierre Claverie, the mission should not follow or depend on a political or military flag ("Sur les pas de drapeaux") but must be mystically rooted in Christ's Cross. In Claverie's words: "The Church errs and deceives the world when it wants to position itself as a great power among others, as a humanitarian organization or as even an evangelical movement of great success. It may shine but it will never succeed in burning with the fire of God's love" (Claverie 1997a, p. 834). The Cross is instead the genuine and final destination of the mission of the Church, because according to Claverie "the Church fulfils its vocation and mission when it is present in the sensible breakpoints that crucify humanity in its flesh and unity" (Pérennès 2000, p. 285). The suffering became, in Claverie's theological thinking, a means by which the mission was decolonised from its political content.

Pierre Claverie's understanding of the death of Christ is another important and last element in the reconstruction of his theology of the mission. In Claverie's view, Christ does not die mainly to erase the original sin, but because not even in front of His Cross, could humanity unite. Our author expresses this concept very simply in just a few words: "An Islamist and a kafir (infidel) cannot be reconciled. So, then, what's the choice? Well, Jesus does not choose. He says I love you all and dies" (Claverie 2015, p. 37). Margron considers that for Claverie "the cross is the tearing asunder of Him who does not wish to choose between two divided sides, for if He entered humanity, He did not do so to reject any part of it. (...) He stands in the midst of divisions and tries to bring the extremes together" (Margron 2004, p. 88). Christ's sacrifice, or the one of any missionaries following His footsteps, is not without sense, but because there is always the hope that true unity can be achieved. Reconciliation is a grace paid with a high price. Jesus died not to forgive sins, not to simply wash away past guilt, but because the true encounter between and with men was missed. A Muslim and a Christian, Claverie uses the words of contempt, derogatory for each one of them, laden with prejudice-cannot come to a consensus and that is why Jesus must die. In Claverie's reading of the Cross, Jesus dies heartbroken over two realities that cannot come to terms. There is almost no Cross; it is not the crucifixion that causes Jesus' death, but it is the missed love, the broken heart. Crucified Jesus cannot choose between those refusing unity, even in front of His Cross, but even not choosing is, in the end, a choice. A question arises: does the Cross remain an event of salvation in Claverie's Christology? Or salvation is, according to him, exactly this: waiting for universal unity to be accomplished and contemplating it without taking part.

The way Pierre Claverie reads the Cross and the death of Christ not only enriches the image of his understanding of mission, but it can fill with new meanings the very term that is now loaded with the prejudice of the past crusader. The crusader is no longer the one who goes on a military mission to impose by force in the Islamic world the Christian way of worshipping the Cross, but the crusader becomes the missionary who goes to those points of the spiritual geography where humanity is crucified by division, trying to heal it by worshipping the most sacred mystery in the world, which is, according to Claverie, human otherness. These aspects give a profound mystical character to Pierre Claverie's theological thinking. 
In front of an imminent personal cross, the bishop of Oran chose to stay in Algeria because he wanted to fulfil what he understood to be a genuine Christian mission. This gave a sense to his life and ministry in the last period of his life; Pierre Claverie confessed in a message: "living every day as being the last one, investing the best of myself, this is giving meaning to a life" (Claverie 1996b, p. 140).

Even if he dedicated his ministry to breaking the link between Christian mission and political colonisation in Algeria, Bishop Pierre Claverie was himself a victim of this link. He was assassinated on 1 August 1996, two months after the beheading of seven other monks kidnapped from the monastery of Tibhirine. He died with his Muslim driver in a bomb blast at the entrance to his episcopal residence. Claverie was the last Christian "missionary" to be killed during the political conflicts of the "black decade". His love for the Algerian people allows us to collocate his martyric death not only among the eighteen other Christian victims ${ }^{21}$ but in a much larger broad context: the victims of the Algerian civil war.

\subsection{For a Mystical Understanding of the Mission}

Taking all of the above into consideration, we could ask: was Pierre Claverie truly a mystic? Having had an important Church administration role and being part of an active order rather than a contemplative one (the Dominican one) do not make him the best candidate for being a mystic in a very evident sense. Nonetheless, his spiritual experience echoed in his words indicate the opposite. There are many definitions of mystics of ecumenism or interfaith dialogue, but we can arrive at a very concrete one: "the mystics aimed to conceive unity not in external ecclesiastical diplomacy terms, but rather to place all the discourse in the light of the mystery of God-the real source of unity", after having their life crossed by a "a spiritual journey, made out of transformative experiences" (Crișan 2020, p. 181).

The already mentioned acquired consciousness of his colonial bubble and of the missed encounter with the Muslim Arab allows us to see a young Pierre Claverie inclined towards reflection. By putting his pilgrimage out of the colonial bubble in the light of God, he transformed his reflection into a transformative spiritual experience. Although he does not admit it openly, Pierre Claverie likely interpreted his path from the colonial bubble into the heart of the other in continuity with other biblical paths. Indeed, he mentions that Abraham, Moses, Mary or Jesus Himself walked a similar path. ${ }^{22}$ The voice that all these biblical characters heard and that changed the path of their lives forever, Claverie heard through the Muslim Algerian. This transformative spiritual experience is the first sign that we deal with a mystic.

Another important sign is of Claverie's mystical thought is the presence of the Cross and of the suffering in his discourse about otherness and encounter. For many mystics, the cross and the suffering play a key role in their spiritual contemplation. For Claverie, the Crucified Christ whispers to him to stay in search of the others in a simple coexistence. By staying in Algeria and risking his own life, Claverie confirmed his inner spiritual solidity and profound love for the humankind, based on Christ's sacrifice. Ten years before his violent death, he wrote:

Living in the Muslim world, I know the weight of this temptation to withdraw into oneself, the difficulty of mutual understanding and of respecting each other. Additionally, I can measure perfectly the abyss that separates us ... We would not be able to bridge this gap by ourselves. However, God, in Jesus, gives us the means to measure the length, the breadth, the depth and the extent of His Love. Supported by this revelation we can regain confidence... To give one's life for this reconciliation as Jesus gave his life to knock down the wall of hatred that separated Jews, Greeks, pagans, slaves, and free men, is not that a good way to honour his sacrifice? (Pérennès 2007b, p. 139) 
However, perhaps the most evident sign of Claverie's mysticism is that he freed the act of faith and thus the concept of mission from any kind of aggression and historical institutionalism in his theological thinking, and he did so by acting according to his intuition gained through a spiritual experience. He fought the heavy burden of the French colonial history of the Church of Algeria and had the courage to create some distance from his own religious beliefs by accepting in Christ a plurality of ways to encounter God. If we accept that the bishop of Oran was truly a mystic, even if a different one, we could also accept that his theological thinking does not have a clear and logic dogmatic system. Claverie expresses more through negations rather than definitions, but this could remind us of the theological apophatic definitions. This may be the reason why we might have the impression that in the writings of Claverie, we find more of what he rejected than what he stood for. Despite his spiritual approach, one must not forget the tough political and social conditions faced by the bishop of Oran when trying to communicate. One of the best summaries of what Claverie stood for is the testimony of a Muslim "spiritual daughter"-Oum El Keir-pronounced at the end of his funeral:

Pierre taught that friendship means first of all common trust in God, love of the other and human solidarity, being a Christian or a Muslim came afterwards, this was not the most important issue at his school; in this school we were taught obedience, dialogue or simply love. Dear friends, today I too am a victim of terrorism, and my flesh has been touched. Dear friends, I am also a victim because I am his Muslim daughter. (N.N. 1997, p. 604)

\section{Conclusions}

In this study, we have set out to find in Pierre Claverie's thought the elements necessary to reconstruct his theological vision of mission. We could summarize by saying that two sources allow us to identify the image of mission in Claverie's thinking: his spiritual experience and the way he reads the history of the Church in Algeria. As expected, the two of them are very much intertwined and it is difficult to say which one takes precedence chronologically, spiritually or even intellectually.

The completely unconventional way in which he refuses official dialogues based on what is common to monotheistic religions or the respect for distances or masks indicates that Claverie was searching for an inner connection with the other, more profound than an institutional official one. At first glance, the bishop does nothing more than reduce the interaction between Christians and Muslims to a simple peaceful coexistence, imposed by the political situation that has come against Christians; at maximum, a friendship of convenience. At a closer look, however, there is something original in his understanding of the mission.

Claverie had a powerful spiritual experience when he realized that he lived his entire youth in a colonial bubble. Due to this experience, the focus of his spiritual attention became the other (in this specific case it is the Algerian Muslim). It is through this lens of otherness that one must understand Claverie's reading of Algeria's colonial history, the mistakes of the Church, the notion of truth, the theology of the Cross and, of course, the role and purpose of the Christian presence in post-colonial Algeria. The reconstruction of the mission according to the theological thinking of Claverie meant looking at all these elements together. This made us observe that there is almost a theological system in all the aspects of Claverie's thinking, based on the sacredness of the other and the acceptance of a spiritual plurality.

The other-object of the mission-is a place of divine presence and therefore a subject of religious contemplation. The mission, in a reversed sense, means searching for the other to find what is divine in him. Therefore, according to our author, a genuine mission does not mean rejecting a priori the truth of others just to impose your own truth, but to contemplate the truth that nobody fully possesses. By giving such a theological understanding to the mission, Claverie succeeds to free it from the burden of colonialism and to strip it of violence and aggression. He does not stand for an obvious numeric result of the mission. 
The fruits of such a mission belong to a spiritual level: contemplation and changing of the heart. The originality of Claverie's theological approach to the mission lies in the fact that the other is so sacred for the act of the mission; that any kind of aggression or seduction, even minor would defile the act of faith. The mission is a contemplative rather than an active process.

For Claverie, the most important fruit of such a reversed mission is the repairing of the colonial history of Algeria. He understood that this goal could only be obtained by freeing the act of faith from any kind of aggression in a spirit of total humbleness and abandon. Claverie disarmed the theology of its proselytising aspect through mentioning the need to accept that more ways lead to God-the differentiated revelation. Even with this acceptance, his faith remained Christologically centred. Of course, more questions could arise for further debate such as: is this model of mission just a consequence of the errors of the French Church in Algeria? How much is Claverie's spiritual experience marked by feelings of an inherited guilt? How much has the political context influenced Claverie? Is this model of mission still relevant for Christians living today in Muslim countries, or for current interreligious dialogue?

Pierre Claverie managed to answer this political reality through his spiritual experience of otherness. The final act of his mission was to remain in Algeria in contemplation of the other and according to his own understanding of the Cross, even with the high price of his own martyrdom. Through his martyric death, Pierre Claverie showed that he spiritually stripped himself of any political opportunism and confirmed that he truly was a mystic of the mission.

Funding: This work was supported by a Hasso Plattner Excellence Research Grant (LBUS-HPI-ERG2020-XX), financed the Knowledge Transfer Center of the Lucian Blaga University of Sibiu.

Institutional Review Board Statement: Not applicable.

Informed Consent Statement: Not applicable.

Data Availability Statement: Not applicable.

Conflicts of Interest: The authors declare no conflict of interest.

\section{Notes}

The expression belogns to Gianni Festa (Festa 2019a, p. 9).

2 The term used to describe people of French or other European origins, born in Algeria during the period of French rule (1830-1962).

3 Cheick, Sheikh = Arabic title of respect dating from pre-Islamic antiquity; it strictly means a venerable man of more than fifty years of age. The title sheikh is especially borne by heads of religious orders, heads of colleges, such as Al-Azhar University in Cairo, chiefs of tribes, and headmen of villages and separate quarters of towns. It is also applied to learned men, especially members of the class of 'ulamā' (theologians), and has been applied to anyone who has memorized the whole Qur'ān, however young he might be. According to Encyclopedia Britannica's definition (2020).

4 For more information on the family's correspondance and their strong relationships see, despite the already-quoted volumes that contain the published letters, the testimony of Pierre's sister: (Gustavson-Claverie 2019).

5 English version according to Pérennès (2000, p. 301).

6 This essay was pubblished for the first time in 1996, just five months before Claverie's death in Nouveaux Cahiers de Sud, republished the same year by Le Monde 4-5 August (1996), included in Pérennès' biography (2000) and finally in the volume Humanité plurielle (Claverie 2008a).

7 For more information on this unconventional Catholic prelate of the twentieth century see: (Duval 2001; Impagliazzo 1994; Ray 1998). The expression belongs to Pérennès (2004, p. 104).

Letter from 1968 quoted by Pérennès (2004, p. 105).

The city of Oran has a very interesting multicultural history, being founded at the beginning of the tenth century by Andalusian merchants as a base for trade with the North African hinterland, and it developed commercially owing to its sea connections with Europe. It was occupied by the Spanish in 1509. For the next two centuries, Oran was contested by the various Mediterranean powers until it fell to the Turks in 1708, who settled a Jewish community there in 1792. Oran was occupied in 1831 by the French, who developed it as a modern port and turned Mers el-Kebir into a major naval base. Oran had a higher proportion of European 
inhabitants than any other North African city, and much strife occurred between the French and the Arab Muslims at the time of Algerian independence in 1962. See: (Britannica 2020).

\section{References}

Borrmans, Maurice. 1996. In Memoriam. Leon-Etienne Duval, Pierre Claverie et Christian de Chergé. Islamochristiana $22:$ 1-8.

Britannica. 2020. The Editors of Encyclopaedia. Encyclopedia Britannica. September 11. Available online: https://www.britannica. $\mathrm{com} /$ topic/sheikh (accessed on 28 December 2021).

Claverie, Pierre. 1986. Difficile rencontre. Documents épiscopaux 4: 7.

Claverie, Pierre. 1991. Temoignage. La Revue du Rosaire 2: 14-20.

Claverie, Pierre. 1995a. Donner sa vie plutôt que de l'arracher aux autres. Peuples du Monde 275: 36-7.

Claverie, Pierre. 1995b. L'invité: Pierre Claverie, eveque d'Oran. L'Actualité Religieuse 15: 39-43.

Claverie, Pierre. 1996a. Humanité plurielle. Les Nouveaux Cahiers du Sud 1: 113-19.

Claverie, Pierre. 1996b. Lettres et Messages d'Algerie. Edited by Vincent Cosmao. Paris: Karthala.

Claverie, Pierre. 1997a. Homélie à Prouilhe le 23 juin 1996. La Vie Spirituelle 721: 833-36.

Claverie, Pierre. 1997b. Itinéraire. La Vie Spirituelle 721: 723-30.

Claverie, Pierre. 1997c. Le mot du père Claverie. La Vie Spirituelle 721: 700-4.

Claverie, Pierre. 1997d. Le sense du dialogue islamo-chrétien. La Vie Spirituelle 721: 705-22.

Claverie, Pierre. 2003a. Donner sa vie, Six Hours de Retraite sur l'Eucharistie. Edited by Jean-Jacques Pérennès. Paris: CERF.

Claverie, Pierre. 2003b. Il est tout de même permis d'être heureux —Lettres Familiales 1967-1969. Edited by Éric Gustavson. Paris: CERF.

Claverie, Pierre. 2004. Petit Traité de la Rencontre et du Dialogue. Paris: CERF.

Claverie, Pierre. 2007. Cette Contradiction Continuellement Vécue. Lettres Familiales 1969-1975. Edited by Éric Gustavson. Paris: CERF.

Claverie, Pierre. 2008a. Humanité Plurielle. Edited by Anne-Catherine Meyer. Paris: CERF.

Claverie, Pierre. 2008b. Marie, la Vivante: Sept Jours de Retraite Avec Marie. Edited by Anne-Catherine Meyer. Paris: CERF.

Claverie, Pierre. 2012. Là où se Posent les Vraies Questions. Lettres Familiales 1975-1981. Edited by Éric Gustavson. Paris: CERF.

Claverie, Pierre. 2015. Mic Tratat Despre întâlnire și Dialog. Translated by Monica Broșteanu. Bucharest: Humanitas.

Crișan, Alexandru-Marius. 2020. The Ecumenism of the Mystics. Editorial RES 2/2020. Review of Ecumenical Studies 2: 181-90. [CrossRef]

Duval, Léon-Étienne. 2001. Au nom de la vérité. Algérie 1954-1962 (Déclarations et lettres de Mgr Duval recueillies par le père Denis Gonzalez et l'historien André Nozière). Paris: Editions Albin Michel. 
Festa, Gianni. 2019a. Cronologia degli anni bui. In Pierre Claverie. La fecondità di una vita donata. Edited by Gianni Festa. Translated by Romeo Fabbri. Bologna: EDB.

Festa, Gianni. 2019b. Pierre Claverie: Una santità domenicana per la Chiesa e per il mondo. In Pierre Claverie. La fecondità di una vita donata. Edited by Gianni Festa. Translated by Romeo Fabbri. Bologna: EDB.

Geffré, Cladio. 1985. La théologie des religions non chrétiennes vinght ans après Vatican II. Islamochristiana 11: 115-53.

Georgeon, Thomas, and Christophe Henning. 2018. Nos vies sont déjà données!: 19 vies pour Dieu et l'Algérie. Le martyre de Mgr Claverie, des moines de Tibhirine et de onze religieuses et religieux. Paris: Bayard.

Gustavson-Claverie, Anne-Marie. 2019. Pierre, mio fratello. In Pierre Claverie. La fecondità di una vita donata. Edited by Gianni Festa. Translated by Romeo Fabbri. Bologna: EDB, pp. 51-60.

Impagliazzo, Marco. 1994. Duval d'Algeria. Rome: Studium Editions.

Margron, Véronique. 2004. Martyre blanc et martyr rouge. Proposition théologique. Topique 4: 81-90. [CrossRef]

Monge, Claudio, and e Gilles Routhier. 2019. Osez l'hospitalité-L'hospitalité à l'école de Pierre Claverie et Christian de Chergé. Montrouge: Bayard.

Monge, Claudio, and e Gilles Routhier. 2020. Il martirio dell'ospitalità. La testimonianza di Pierre Claverie e Christian de Chergé. Edited by Giovanni Ibba. Bologna: EDB.

N.N. 1997. La messe. La Vie Spirituelle 721: 597-606.

Naylor, Phillip C. 2010. Bishop Pierre Claverie and the Risks of Religious Reconciliation. The Catholic Historical Review 96: 720-42.

Pérennès, Jean-Jacques. 2000. Pierre Claverie: Un Algérien par alliance. Paris: CERF.

Pérennès, Jean-Jacques. 2004. Vescovo tra i musulmani. Pierre Claverie martire in Algeria. Foreword by Timothy Radcliffe. Translated by Raimondo Sorgia. Rome: Città Nuova.

Pérennès, Jean-Jacques. 2007a. A Life Poured Out. Pierre Claverie of Algeria. Translated by Matthew Sherry, and Phyllis Jestice. Maryknoll and New York: Orbis Books.

Pérennès, Jean-Jacques. 2007b. The Legacy of Pierre Claverie. International Bulletin of Missionary Research 31: 136-42. [CrossRef]

Pérennès, Jean-Jacques. 2018a. Pierre Claverie et Christian de Chergé, deux regards sur le mystère de l'islam. Islamochristiana 45: 191-203.

Pérennès, Jean-Jacques. 2018b. Pierre Claverie, la fécondité d'une vie donnée. Paris: CERF.

Pérennès, Jean-Jacques. 2019. Alcuni punti fermi nella vita intensa e feconda di Pierre Claverie. In Pierre Claverie. La fecondità di una vita donata. Edited by Gianni Festa. Translated by Romeo Fabbri. Bologna: EDB, pp. 37-49.

Ray, Marie-Christine. 1998. Le Cardinal Duval, un homme d'espérance en Algérie. Paris: Cerf.

Salenson, Christian. 2020. Cette Eglise révélée par les martyrs d'Algérie: Retraite à Tibhirine. Bruyères-le-Châtel: Nouvelle Cité.

Sudworth, Richard J. 2014. Responding to Islam as Priests, Mystics, and Trail Blazers: Louis Massignon, Kenneth Cragg and Rowan Williams. Logos: A Journal of Eastern Christian Studies 55: 451-72.

Taith, Bertrand. 2006. Algerian Orphans and Colonial Christianity in Algeria, 1866-1939. French History 20: 240-59. [CrossRef] [PubMed] Tessier, Henri. 2019. Pierre Claverie e l'Islam. In Pierre Claverie. La fecondità di una vita donata. Edited by Gianni Festa. Translated by Romeo Fabbri. Bologna: EDB, pp. 67-79. 